\title{
THE TAYLOR RULE AND THE EXCHANGE RATE IN MEXICO (AN EMPIRICAL APPRAISAL)
}

\author{
Luis Miguel Galindo* \\ Facultad de Economía \\ Universidad Nacional Autónoma de México \\ Horacio Catalán \\ Facultad de Economía \\ Universidad Nacional Autónoma de México \\ (Received 15 April 2005, accepted 3 June 2005)
}

\begin{abstract}
The objective of this paper is to analyze the relevance of the Taylor rule, including the real exchange rate, for the Mexican case. The main results indicate that a simple rule appropriately describes the reaction function of the Mexican Central Bank. The inclusion of the real exchange rate is statistically significant and has the correct signs in the parameters. That is, an appreciation of the real exchange rate induces a relaxation of the monetary policy. However, the inclusion of the real exchange rate only marginally improves the Taylor rule for a closed economy.
\end{abstract}

\section{Resumen}

El objetivo de este trabajo es analizar la validez de la regla de Taylor, incluyendo el tipo de cambio real, para el caso de la economía mexicana. La evidencia empírica indica que una regla simple describe apropiadamente la función de reacción del Banco de México. La inclusión del tipo de cambio real es estadísticamente significativo de modo que una apreciación real del peso mexicano induce una política monetaria más flexible. Sin embargo, la inclusión del tipo de cambio real mejora sólo marginalmente los resultados de una regla de Taylor para una economía cerrada.

JEL classification: $C 22, E 52, E 58$

Keywords: Taylor's rule, Monetary Policy, Real Exchange Rate

* Posgrado en Economía, UNAM. Avenida Universidad no. 3000, Ciudad Universitaria, Oficinas administrativas núm. 2, primer piso, c.p. 04510, Delegación Coyoacán, México, D. F.. Telephone: +52 (55)5622-2341 / 43 / 85. E-mail: gapaliza@servidor.unam.mx

We acknowledge the financial support from the PAPIIT-UNAM project IN: 304702 . The usual disclaimer applies. 


\section{Introduction}

Over the past few years, the interest in studying the formulation and evaluation of monetary policy rules (Taylor (1999a)) has increased. In literature the Taylor (1993) rule is, arguably, the most common model used for the description of the monetary policy reaction function of the Central Bank. There is, however, an increasing concern (Taylor (2001); Ball (1997); Batini, Harrison, and Millard (2001)) about the ability of this rule to incorporate the exchange rate channel of monetary transmission, in particular in the case of small open economies.

In the Mexican case, as a consequence of recent changes in the institutional framework and because of the effect of the exchange rate channel on these conditions, there is an increasing interest in the relevance of a monetary policy rule for the nominal interest rates. That is, since 1995, the Mexican Central Bank has gradually oriented its monetary policy to influence nominal interest rates through an indirect mechanism called "el corto". ${ }^{1}$ In this context, the application of a monetary rule based on the nominal interest rate has acquired preeminence. Additionally, there is increasing evidence for the importance of the exchange rate channel in the definition of the Mexican monetary policy (Carstens and Werner (1999)). In this sense, a few studies of the Mexican economy (Ortiz (2000); and Martínez, Sánchez, and Werner (2001)) have estimated a Taylor rule that includes the effect of the real exchange rate on the real interest rate, but these do not consider the nominal interest rate.

Therefore, the Inain objective of this paper is to analyze the importance of the exchange rate factor in the Taylor rule by using the nominal interest rate as the endogenous variable for the Mexican economy over the period 1980-2002. The paper is organized as follows. The next section includes the empirical evidence and the last section presents the conclusions and some general comments.

\section{The empirical evidence of the Taylor Rule and the exchange rate}

The Mexican Central Bank ${ }^{2}$ has the objective to control the inflation rate using a mechanism called "el corto". This mechanism influences the nominal interest rate through the impact on the liquidity of the financial system (Díaz de León and Greenham (2001); and Castellanos (2000)). That is, the Central Bank imposes a certain penalty for the additional liquidity of the private banks, thus forcing them to raise the entire interest rate structure. In this sense, the Mexican Central Bank uses the nominal interest rate as the main component of its monetary policy and there is, therefore, an increasing concern about the elaboration of monetary policy rules that use the nominal interest rates as their endogenous variable.

The original Taylor rule (Taylor (1993)) argues that the nominal interest rate adjusts as a response to changes in inflation and output from a target. There are alternative specifications of this rule (see for example Taylor (1999a); Rotemberg and Woodford (1999); Clarida, Galí, and Gertler (1999)). However, recent research on policy rules Ball (1998); Batini, Harrison and Millard

1 For an explanation of this mechanism see "Anexo 4 del Informe Anual del Banco de México 1996" and for its effects see Gil Díaz (1997); Díaz and Greenham (2001); and Castellanos (2000)).

2 Banco de México (1993). 
(2001); Taylor (1999c); Taylor (2001); and Clarida, Galí, and Gertler (2001) has argued that, in an open economy, the exchange rate is an important part of the transmission mechanism of monetary policy and that it is, therefore, important to explicitly include this variable into the original specification of the Taylor rule. Therefore, a general specification of the these two policy rules ${ }^{3}$ can be represented as follows (Taylor (1999a, 2001)):

$$
\begin{gathered}
R_{t}=\beta_{1} \pi_{t}+\beta_{2} y_{t}^{g}+\beta_{3} R_{t-1}+u_{t}, \\
R_{t}=\beta_{1} \pi_{t}+\beta_{2} y_{t}^{g}+\beta_{4} s r_{t}+\beta_{5} s r_{t-1}+u_{t},
\end{gathered}
$$

where $\pi_{t}$ is the inflation rate, $y_{t}^{g}$ is the deviation of real GDP from potential $G D P, s r_{t}$ is the real exchange rate (an increase is a real appreciation) and $u_{t}$ is the error term. Small letters are the natural logarithm of the series.

Equation (1) assumes that the interest rate responds to actual inflation, the expected output gap and the previous value of interest rate and the parameter $\beta_{3} \in[0,1]$ captures the degree of interest rate smoothing. The expected values of the coefficients of equation (1) express the idea that the Central Bank pursues a "lean against the wind policy" (Clarida, Galí, and Gertler (1999)) with $\beta_{1}>0$, $\beta_{2}>0$ and a gradual adjustment process $\beta_{3}>0$. In the other side, the parameters $\beta_{4}$ and $\beta_{5}$ express the role of the exchange rate in the policy rule. Then, in the case that $\beta_{4}=0$ and $\beta_{5}=0$ only the domestic factors are relevant for the policy rule. On the contrary, in the case that these parameters are nonzero, several authors (Obstfeld and Rogoff (1995); Taylor (2001); Ball (1998); and Svensson (2000)) argue that $\beta_{4}<0$ and $\beta_{5}=0$ or $\beta_{5}>0$ with $\beta_{4}$ bigger, in absolute value, to $\beta_{5}$. Furthermore, in the case that $\beta_{4}<0$ and $\beta_{4}=-\beta_{5}$ then the relevant variable is the change of the real exchange rate. These parameter values indicate that a higher real exchange rate implies a reduction in the nominal interest rate, which implies a more "flexible monetary policy" (Taylor (2001)).

The empirical evidence gathered in this paper is based on unadjusted quarterly series covering the period from 1980(1) to 2004(4). ${ }^{4}$ The $R_{t}$ is the three month nominal interest rate of the public bond call CETES, $\pi_{t}\left(\pi_{t}=\right.$ $100^{*}\left(p_{t}-p_{t-1}\right)$ is the inflation rate of the consumer price index $\left(p_{t}\right), y_{t}^{g}$ is the deviation of the real Gross Domestic Product from the potential output $\left(y_{t}^{g}=100^{*}\left(y_{t}-y h p_{t}\right)\right)$ obtained using the Hodrick-Prescott filter (1997) $\left(y h p_{t}\right)$. The real exchange rate $\left(s r_{t}\right)$ is defined as an appreciation and it is represented above the base line.

The estimation of the Taylor rule, in any of its specifications, requires a careful consideration of the statistical properties of the series. This is because

3 There are alternative specifications of each variable and also of the number of lags. In particular we use the annual inflation rate instead of the gap between the actual inflation and the inflation target. We basically do this, because, during the eighties, the main target of the Mexican authorities was to reduce price expectations and it, therefore, does not represent a good approximation of the truth target. Additionally, policy-makers are more concerned with medium and longer term price trends than month to month variations (Clarida, Galí, and Gerlter (1998)).

4 The definition of the variables is in the Appendix. 
the estimation of the Taylor rule might be subject to the critic of the spurious regression problem because of the use of series $I(1)$. However, the order of integration of the series is not clear-cut considering the possible presence of structural breaks in the Mexican case. This is because it is difficult to distinguish between a stationary series with structural break and a non-stationary series with genuine unit roots (Kim and Maddala (1998)). In order to reduce this potential problem we use a battery of unit root tests that allow for structural breaks in the series.

Therefore, we initially estimate the standard Augmented Dickey-Fuller (1981), Phillips-Perron (1988) and Kwiatkowsky et al. (1992) tests (KPSS). In the ADF and PP we use a "general to specific" procedure by, initially, estimating a regression with constant and trend, testing their significance. The lag length $(k)$ is chosen using the $t$-sig procedure ( $\mathrm{Ng}$ and Perron (1995)) selecting a number of lags $(k)$ equal to 8 and then reducing the equation until the last lag becomes statistically significant.

Finally, we proceed to test for the possible presence of structural change by means of the Perron (1997) test. This statistic makes the break point endogenous, using the null hypothesis as unit root process without any structural breaks and the alternative as a trend stationary process with possible structural change (Perron (1997)).

The standard unit root tests, summarized in Tables 1 and 2, indicate that the output gap is a stationary series. However, the order of integration of nominal interest rates, the inflation rate and the real exchange rate raise several important issues. Normally, the standard Augmented Dickey-Fuller (ADF) (1981), Phillips-Perron (PP) (1988), and the KPSS (1992) tests indicate that nominal interest rates, the inflation rate and the the real exchange rate in the Mexican case are I(1) (Table 1). However, these series might be considered I(0) including structural changes or regimen shifts (Campbell, Loo, and MacKinlay (1997)). In particular, the Perron (1997) test (Table 2) indicates that appropriate consideration of the structural break in 1987 leads to the conclusion that $R_{t}, \pi_{t}$ and $s r_{t}$ are all $\mathrm{I}(0)$. These results are consistent with the idea that the interest rate is stationary in each policy regimen (McCallum and Nelson (1999), pp 30).

Additionally, economic theory suggests that nominal interest rates and the inflation rate cannot grow with an upper limit. Therefore, we proceed on the basis that, when the potential presence of structural change is considered, all the series are stationary.

The specification assumes that the Central Bank does not have all the relevant information available about the state of economy (Clarida, Galí, and Gertler (1999)). With imperfect information, the reaction function can be expressed in terms of an information set that is orthogonal to $u_{t}$. Therefore, in order to estimate the parameters of these equations we use the General Method of Moments (GMM) (Hansen (1982)) correcting for possible autocorrelation of order 4 using Newey and West (1987) declining weights (Table 3). Finally, we evaluate if the model is over identified using the $\mathrm{J}$ test (Hansen (1982)). The instrument set includes one to four lagged values of the nominal interest rates, the inflation rate and deviations form output for equation (1) and also the 
Table 1. Unit Root Tests.

\begin{tabular}{cccc}
\hline Variables & \multicolumn{3}{c}{$\mathrm{ADF}$} \\
& & $\mathrm{B}$ & $\mathrm{C}$ \\
\hline$R_{t}$ & $-3.07(0)$ & $-2.09(0)$ & $-1.33(0)$ \\
$\Delta R_{t}$ & $-\mathbf{9 . 1 8}(\mathbf{1})$ & $-\mathbf{9 . 1 7}(\mathbf{1})$ & $-\mathbf{9 . 2 1}(\mathbf{1})$ \\
& & & \\
$\pi_{t}$ & $-\mathbf{3 . 7 4}(\mathbf{5})$ & $-2.06(5)$ & $-1.63(5)$ \\
& & & \\
$\Delta \pi_{t}$ & $-\mathbf{3 . 4 4}(\mathbf{8})$ & $-\mathbf{3 . 4 8}(\mathbf{8})$ & $-\mathbf{3 . 4 0}(\mathbf{8})$ \\
& & & \\
$g a p y_{t}$ & $-\mathbf{4 . 0 9}(\mathbf{8})$ & $-\mathbf{4 . 1 3}(\mathbf{8})$ & $-\mathbf{4 . 1 6}(\mathbf{8})$ \\
& & & \\
$s r_{t}$ & $\mathbf{- 3 . 8 0}(\mathbf{3})$ & $-\mathbf{3 . 1 1}(\mathbf{3})$ & $-0.48(0)$ \\
& & & \\
$\Delta s r_{t}$ & $\mathbf{- 4 . 7 5}(\mathbf{5})$ & $-\mathbf{4 . 6 8}(\mathbf{5})$ & $-\mathbf{4 . 7 1}(\mathbf{5})$ \\
\hline
\end{tabular}

Table 1. (continue)

\begin{tabular}{|c|c|c|c|c|c|}
\hline \multirow[t]{2}{*}{ Variables } & \multicolumn{3}{|c|}{ PP } & \multicolumn{2}{|c|}{ KPSS } \\
\hline & A & $\mathrm{B}$ & $\mathrm{C}$ & $\eta_{\tau}$ & $\eta_{\mu}$ \\
\hline$R_{t}$ & $-3.01(5)$ & $-2.01(5)$ & $-1.20(5)$ & 0.0874 & 0.5293 \\
\hline$\Delta R_{t}$ & $-10.19(5)$ & $-10.19(5)$ & $-10.24(5)$ & 0.0810 & 0.1298 \\
\hline$\pi_{t}$ & $-2.96(5)$ & $-1.80(5)$ & $-2.06(5)$ & 0.0729 & 0.6529 \\
\hline$\Delta \pi_{t}$ & $-3.80(5)$ & $-3.81(5)$ & $-3.83(5)$ & 0.0764 & 0.0978 \\
\hline$g a p y_{t}$ & $-8.96(5)$ & $-8.99(5)$ & $-9.02(4)$ & 0.0410 & 0.0410 \\
\hline$s r_{t}$ & $-2.79(5)$ & $-2.50(5)$ & $-0.51(5)$ & 0.0995 & 0.2708 \\
\hline$\Delta s r_{t}$ & $-9.63(5)$ & $-9.66(5)$ & $-9.69(5)$ & 0.0710 & 0.1012 \\
\hline
\end{tabular}

Notes: Tests statistics in bold indicate a rejection of the null hypothesis. Critical values at 5\% significance level for the Augmented Dickey-Fuller and Phillips-Perron tests for a size $\mathrm{T}=100$ are -3.45 including constant and trend (model A), -2.89 including constant (model B), and -1.95 without constant and trend (model C) (Maddala and Kim (1998), p. 64). $\eta_{\mu}$ and $\eta_{\tau}$ is the KPSS test for the null hypothesis of stationarity around a level and deterministic linear trend, respectively. Both test are calculated with a lag window size equal to 9 . The $5 \%$ critical values for the two test are 0.463 and 0.146 , respectively (Kwiatkowski et al. (1992), p. 166). 
Table 2. Perron (1997) Unit Root Tests.

\begin{tabular}{cccc}
\hline Model & \multicolumn{3}{c}{$R_{t}$} \\
\hline & $k(t-\operatorname{sig})$ & $\hat{t}_{(\hat{\alpha}-1)}$ & $\begin{array}{c}\text { Break } \\
\text { date }\end{array}$ \\
\hline IO1 & 7 & -4.479 & $1987: 03$ \\
IO2 & 2 & $-\mathbf{7 . 0 6 1}$ & 1987.03 \\
A0 & 0 & -3.001 & $1980: 04$ \\
\hline
\end{tabular}

Table 2. (continue)

\begin{tabular}{cccccc}
\hline Model & \multicolumn{2}{c}{$\pi_{t}$} & & \multicolumn{2}{c}{$t_{\alpha}^{*}(T=100)$} \\
\hline & $k(t-s i g)$ & $\hat{t}_{(\hat{\alpha}-1)}$ & $\begin{array}{c}\text { Break } \\
\text { date }\end{array}$ & $5 \%$ & $10 \%$ \\
\hline IO1 & 5 & -4.805 & $1990: 01$ & -5.10 & -4.82 \\
IO2 & 5 & -6.620 & $1987: 04$ & -5.55 & -5.25 \\
A0 & 1 & -3.840 & $1993: 02$ & -4.83 & -4.48 \\
\hline
\end{tabular}

Notes: IO1 innovational outlier with a change in the intercept; IO2 innovational outlier with a change in the intercept and in the slope and $\mathrm{AO}$ additive outlier with a change in the slope but both segments of the trend function are joined at the time break. $t_{\alpha}^{*}$ critical values at the $5 \%$ and $10 \%$ significance level for each model (Perron (1997), table 1). Test statistics in bold indicate rejection of the null hypothesis a $5 \%$ significance level.

change of the real exchange rate in equation (7). ${ }^{5}$

We estimate, initially, a simple Taylor rule including only domestic factors with and without an interest rate adjustment and afterwards, to account for the potential influence of the real exchange rate, equation (2). The econometric results, summarized in Table 3, indicate that simple rules have a satisfactory explicative power over the formulation of the monetary policy in Mexico. Additionally, the $\mathrm{J}$ test shows that the model does not reject the over identifying restrictions. Equations (3) and (4) are representations of the Taylor rule considering only domestic factors while equations (5), (6), and (7) include the real

5 See Mehra (1999) for details for the estimation procedure. 
exchange rate and the change in the real exchange rate. All these models show that a simple rule has important predictive power over the monetary policy in Mexico.

Table 3. Estimates of Taylor rule by GMM 1982:1 2004:4.

\begin{tabular}{|c|c|c|c|c|c|}
\hline \multirow[t]{2}{*}{ Variables } & \multicolumn{5}{|c|}{ Equations } \\
\hline & (3) & (4) & (5) & (6) & $(7)$ \\
\hline \multirow[t]{2}{*}{$C$} & 6.08 & -0.21 & & -0.10 & \\
\hline & {$[0.00]$} & {$[0.88]$} & & {$[0.91]$} & \\
\hline \multirow[t]{2}{*}{$g a p y_{t}$} & 0.21 & 0.54 & 0.44 & 0.47 & 0.44 \\
\hline & {$[0.39]$} & {$[0.05]$} & {$[0.07]$} & {$[0.03]$} & {$[0.053]$} \\
\hline \multirow[t]{2}{*}{$\pi_{t}$} & 0.95 & 0.13 & 0.151 & 0.153 & 1.16 \\
\hline & {$[0.00]$} & {$[0.02]$} & {$[0.00]$} & {$[0.00]$} & [0.00] \\
\hline \multirow[t]{2}{*}{$R_{t-1}$} & & 0.88 & 0.870 & 0.871 & \\
\hline & & {$[0.00]$} & {$[0.00]$} & {$[0.00]$} & \\
\hline \multirow[t]{2}{*}{$s r_{t}$} & & & -0.416 & & \\
\hline & & & {$[0.00]$} & & \\
\hline \multirow[t]{2}{*}{$s r_{t-1}$} & & & 0.415 & & \\
\hline & & & {$[0.00]$} & & \\
\hline \multirow[t]{2}{*}{$\Delta s r_{t}$} & & & & -0.63 & -0.63 \\
\hline & & & & {$[0.00]$} & {$[0.047]$} \\
\hline$R^{2}$ & 0.733 & 0.826 & 0.852 & 0.869 & 0.720 \\
\hline Hamsen's & $\chi^{2}(10)=$ & $\chi^{2}(9)=$ & $\chi^{2}(8)=$ & $\chi^{2}(8)=$ & $\chi^{2}(12)=$ \\
\hline J-test & $8.50(0.58)$ & $7.44(0.59)$ & $5.63(0.68)$ & $5.22(0.73)$ & $10.2(0.59)$ \\
\hline
\end{tabular}

Notes: The set the instruments includes four lags of inflation, output gap, nominal interest rate and real exchange rate. $p$-value in braches are below the coefficient estimates.

In the case of a Taylor rule that includes only domestic factors it is possible to argue that the nominal interest rates respond to the inflation rate, the output gap and the interest rate with one lag. On the other hand, equations (5), (6), and (7) indicate that the nominal interest rate responds to the inflation rate and the real exchange rate or the change of the real exchange rate and, possibly, to the output gap. The relevance of the exchange rate is consistent with Ortiz (2000); and Martínez, Sánchez, and Werner (2001). It is worth noticing that the restriction of $\beta_{4}=-\beta_{5}$ is valid for the Mexican case (equation (5)) and therefore equations (6) and (7) are the best options including the change in the real exchange rate. In this sense, the Mexican Central Bank basically orients its monetary policy to control the inflation rate and to offset the effects of the changes of the real exchange rate on the economy. For example, an appreciation 
of the exchange rate has a negative effect on output that the Central Bank tries to compensate through the reduction of the nominal interest rate (Obstfeld and Rogoff (1995)). The sign on the coefficient of the exchange rate is consistent with the results of Ball (1998) and Taylor (1999b) and indicates that the Taylor rule, in the Mexican economy, improves its performance when the real exchange rate is included, similar to the cases of Italy and France. It is worth noticing that the output gap is only statistically significant excluding the constant (equation (7)).

Additionally, it is also worth noticing that in equations (3) and (5) the output gap is not statically significant. This evidence is consistent with the estimations of Clarida, Galí, and Gertler (1999) for the United States after 1979 and implies that the Mexican Central Bank is only responding to the output gap through its predictive power over inflation. That is, when the output gap is used as an instrument in the GMM estimation then the parameter in the equation only reflects its influence, independent of its effect through the inflation rate (Clarida, Galí, and Gertler (1999)).

However, the general evidence indicates that the improvement, including the real exchange rate, is not fundamental. Furthermore, the satisfactory performance of the Taylor rule, excluding the exchange rate, suggests that the effect of this variable is captured, indirectly, by means of the inflation rate and the output channels. That is, an appreciation of the exchange rate leads to a reduction of the inflation rate and a lower output and will, therefore, impact the adjustment of the nominal interest rate (Taylor (2001)) by means of these variables. In this sense, the real exchange rate impacts, with lags, the nominal interest rate through the domestic variables.

\section{Conclusions and General Comments}

The empirical evidence indicates that, when simulating the monetary policy reaction of the Mexican Central Bank, a simple rule performs relatively well. In this sense, the nominal interest rate responds to the inflation rate, the output gap, the lag of the interest rate and/or the change of the real exchange rate.

The main results indicate that the Taylor rule, excluding the exchange rate, performs relatively well when simulating the actual movements of the nominal exchange rate. The inclusion of the exchange rate in the Taylor rule improves the properties of the equation. This small improvement occurs because the effect of the change in the exchange rate is partially offset by the lagged impact of this movement on inflation and the inclusion of the nominal interest rate with one lag (Taylor (2001)). These results give a partial answer to the question of how exchange rates should be taken into account when formulating monetary policy (Taylor (2001)), indicating the strong relationship between the inflation rate, the nominal interest rate and the exchange rate in Mexico. For example, the Mexican evidence suggests that explicit interest rate targets generate a higher volatility in the exchange rate (Schwartz, Tijerina, and Torre (2002); and Martínez, Sánchez, and Werner (2001)) as well as the existence of a strong relationship between the exchange rate depreciation and the inflation rate (Carstens and Werner (1999)).

In this sense, the empirical evidence gathered in this paper indicates that the exchange rate is an important factor to be considered in the elaboration of 
the monetary policy in Mexico. However, its impact is partially captured by the movement of other variables such as the inflation rate or the output gap. Therefore, the improvement of the Taylor rule by including the exchange rate is only marginal.

\section{Appendix}

\section{Data sources}

The data are seasonally quarterly data from $1980(1)$ to $2004(4)$. The nominal interest rate is the average three months of the public bonds call CETES, the inflation rate is $\pi_{t}=100^{*}\left(p_{t}-p_{t-1}\right)$ and $p_{t}$ is the natural logarithm of the consumer price index, the output gap is defined as $y_{t}^{g}=\left(y_{t}-y h p_{t}\right)$, where $y_{t}$ is the Gross Domestic Product (GDP) and $y h p_{t}$ is the GDP trend obtained using the Hodrick-Prescott filter (1997).

\section{References}

Ball, L. (1997). Efficient Rules for Monetary Policy. NBER, Working Paper 5952, pp. 1-22. Ball, L. (1998). Policy Rules for Open Economic. NBER, Working Paper 6760, pp. 1-30. Banco de México (1993). Ley del Banco de México.

Banco de México (1997). Informe Anual 1996.

Batini, N., R. Harrison, and S. Millard (2001). Monetary Policy Rules for an Open Economy. Working Paper 149, Bank of England, pp. 1-54.

Campbell, J., A. Loo, and A. Mackinlay (1997). The Econometrics of Financial Markets. Princeton University Press.

Carstens, A. and A. Werner (1999). Mexico's Monetary Policy Framework under a Floating Exchange Rate Regime. Documento de Investigación No. 9905, Banco de México, pp. $1-52$.

Castellanos, S. (2000). El efecto del "corto" sobre la estructura de tasas de interés. Documento de Investigación No. 2000-1, Banco de México, pp. 1-41.

Charemza, W. and E. Syczewska (1998). Joint Aplication of the Dickey Fuller and KPSS Tests. Economic Letters, 61, pp. 17-21.

Clarida, R., J. Galí, and M. Gertler (1998). Monetary Policy Rules in Practice. Some International Evidence. European Economic Review, 42, pp. 1033-1067.

Clarida, R., J. Galí, and M. Gertler (1999). The Science of Monetary Policy: A new Keynesina Perspective. Journal of Economic Literature, 37, pp. 1661-1707.

Clarida, R., J. Galí, and M. Gertler (2001). Optimal Monetary Policy in open Versus Closed Economies: an Integrated Approach. it American Economic Review, 91(2), pp. 248-252.

Cogley, T. ang J. Nason (1995). Effects of the Hodrick-Prescott Filter on Trend and Difference Stationary Time Series. Implications for Business Cycle Research. Journal of Economics Dynamics and Control, 19, pp. 253-278.

Davinson, R. and J. Mackinnon (1993). Estimation and Inference in Econometrics. Oxford Univedrsity Press.

Díaz de León, A. y L. Greenham (2001). Política monetaria y tasas de interés: experiencia reciente para el caso de México, Economía Mexicana, Nueva Época, 10(2), pp. 213-258.

Dickey, D. and W. Fuller (1981). Likelihood Ratio Statistics for Autoregressive Time Series with a Unit Root. Econometrica, 49(4), pp. 1057-1077.

Fuhrer, J. and G. Moore (1995). Monetary Trade-Offs and the Correlation between Nominal Interest Rates and Real Output. American Economic Review, 85(1), pp. 219-239.

Gil-Díaz, F. (1997). Lá política monetaria y sus canales de transmisión en México. Gaceta de Economía, suplemento, ITAM, 3(5), pp. 79-102.

Hansen, L. (1982). Large Sample Properties of Generalized Method of Moments Estimators. Econometrica, 50, pp. 1029-1054. 
Harvey, A. and A. Jaeger (1993). Detrending, Stylized Facts and the Business Cycle. Journal of Applied Econometrics, 8, pp. 231-247.

Hodrick, R. and E. Prescott (1997). Postwar U.S. Business Cycles: an Empirical Investigation. Journal of Money Credit and Banking, 29(1), pp. 1-16.

Johansen, S. (1995). Likelihood-Based Inference in Cointegrated Vector Auto-Regressive Models. Advanced Texts in Econometrics, Oxford University Press.

Kwiatkowski, D., P. Phillips, P. Schmidt, and Y. Shin (1992). Testing the Null Hypothesis of Stationary Against the Alternative of a Unit Root. Journal of Econometrics, 54, pp. 159-178.

Maddala, G. and I. Kim (1998). Unit Roots, Cointegration and Structural Change. Cambridge University Press.

Martínez, L., O. Sánchez, and A. Werner (2001). Consideraciones sobre la conducción de la política monetaria y el mecanismo de transmisión en México. Documento de investigación, No. 2001-02, Banco de México, pp. 1-50.

Mehra, Y. (1999). A Forward-Looking Monetary Policy Reaction Function. Federal Reserve Bank of Richmond Economic Quarterly, 85(2), pp. 33-53.

McCallum, B. and E. Nelson (1999). Performance of Operational Rules in an Estimated Semiclassical Structural Model. In Taylor, J. (Ed.). Monetary Policy Rules. National Bureau of Economic Researc, Unviersity of Chicago Press, pp. 15-56.

Mishkin, F. (1992). Is the Fisher effect for Real? A Reexamination of the Relationship between Inflation and Interest Rates. Journal of Monetary Economics, 30, pp. 195215.

Newey, W. and W. Kenneth (1987). A Simple Positive Semi-Definite, Heteroskedasticity and Autocorrelation Consistent Covariance Matrix. Econometrica, 55, pp. 703-708.

$\mathrm{Ng}, \mathrm{S}$. and P. Perron (1995). Unit Root Tests in ARMA Models with Data Depend Methods for the Selection of the Truncation Lag. Journal of the American Statistical Association, 90, pp. 268-281.

Obstfeld, M. and K. Rogoff (1995). The Mirage of Fixed Exchange Rates. Journal of Economic Perspectives, 9(4), pp. 73-96.

Ortiz, G. (2000). How Should Monetary Policy Markets React to the New Challenges of Global Economic Integration: the Case of Mexico. Prepared for the Symposium Global Economic Integration: Opportunities and Challenges, sponsored by the Kansas City Fed, Jackson Hole Wyoming, pp. 1-22

Patterson, P. (1997). An Introduction to Applied Econometrics: a Time Series Approach. St. Martin Press.

Perron, P. (1997). Further Evidence on Breaking Trend Functions in Macroeconomics Variables. Journal of Econometrics, 80, pp. 355-385.

Perron, P. (1989). The Great Crash, the Oil Price Shock and the Unit Root Hypothesis. Econometrica, 57(6), pp.1361-1401.

Phillips, P. and P. Perron (1988). Testing for Unit Root in Time Series Regression. Biométrica, 75 , pp. 335-346.

Rotemberg, J. and M. Woodford (1999). Interest Rate Rules in an Estimated Sticky Price Model. In Taylor, J. (Ed.). Monetary Policy Rules. National Bureau of Economic Research, University of Chicago Press, pp. 319-348.

Rotemberg, J. (1987). The new Keynesian Microfundations. In Ficher, S. (Ed.). NBER, Macroeconomics Annual, MIT Press, pp. 297-346.

Schwartz, M. J., A. Tijerina, and L. Torre (2002). Volatilidad del tipo de cambio y tasas de interés en Méxic: 1996-2001. Economía Mexicana, Nueva Época, 11(2), pp. 299-331.

Svensson, L. (2000). Open-economy inflation targeting. Journal of iNternational Economics, 50(1), pp. 155-183.

Svensson, L. (1997). Inflation Forecast Targeting: Implementation and Monitoring Inflation Targets. European Economic Review, 41, pp. 1111-1147.

Taylor, J. (1993). Discretion Versus Policy Rules in Practice. Carnegie-Rochester Conference Series on Public Policy, 39, pp. 195-214. 
Taylor, J. (1999a). Monetary Policy Rules. National Bureau of Economic Researc, Unviersity of Chicago Press.

Taylor, J. (1999b). A historical analysis of monetary policy rules. In Taylor, J. (Ed.). Monetary Policy Rules. National Bureau of Economic Researc, Unviersity of Chicago Press, pp. 319-348.

Taylor, J. (1999c). The Robustness and Efficiency of Monetary Policy Rules as Guidelines for Interest Rates setting by the European Central Bank. Journal of Monetary Economics, $43(3)$, pp. 655-679.

Taylor, J. (2001). The Role of the Exchange Rate in Monetary-Policy Rules. American Economic Review Papers and Proceedings, 91(2), pp. 263-267.

Walsh, C. (2000). Monetary Theory and Policy. MIT Press.

Woodward, B. (2001). Greenspan. Península Atalaya. 